\title{
INVESTIGATION OF THE EFFECT OF SLENDERNESS RATIO ON THE STRUCTURAL RESPONSE OF MASONRY MINARETS
}

\author{
Özden SAYGILI ${ }^{1, *}$ \\ Yeditepe Üniversitesi, Mühendislik Fakültesi, İnşaat Müh. Böl., İstanbul
}

\begin{abstract}
Recent large earthquakes (eg, the Mw7.2, 2011 Van, Turkey, earthquake and the Mw6.6, 2017 Muğla, Turkey, earthquake) have shown that the vulnerability of slender masonry minarets under seismic loadings. The response of minarets to seismic excitations are different from other form structures because of their complex behavior due to geometrical changes in the cross section of bodies, height and slenderness ratio. The purpose of the present study is to evaluate the effect of slenderness ratio of masonry minarets when they are subjected to ground motion and to quantify the impact of this parameter on structural demands, such as top displacement, stress and torsional moment. To this aim, six masonry minarets with different height and drum diameter were numerically created and subjected to synthetic seismic loadings created for four ground motion levels. As it is difficult to determine the slenderness ratio for varying diameters, it was investigated in two ways.
\end{abstract}

Keywords: Masonry minarets, Earthquake response, Slenderness

\section{YIĞMA MINARELERIN YAPISAL DAVRANIŞINA NARINLIKK ORANI ETKİSININ İNCELENMESI}

\begin{abstract}
ÖZET
Son zamanlarda meydana gelen büyük depremler (örneğin, Mw7.2, 2011 Van, Türkiye depremi ve Mw6.6, 2017 Muğla, Türkiye depremi) yığma minarelerinin sismik yükler altında hasar aldığını göstermiştir. Minarelerin deprem davranışı, geometrik yapılarının farklılığı, yükseklik ve narinlik oranı nedeniyle diğer yapılardan farklıdır. Bu çalışmanın amacı, yığma minarelerin yer hareketine maruz kaldıklarında, narinlik oranının yapısal davranışlarına etkisini değerlendirmek ve bu parametrenin yapıda meydana gelen maksimum yer değiştirme, gerilme ve burulma momenti gibi yapısal talepler üzerindeki etkisini ölçmektir. Bu amaçla, farklı yükseklik ve çapa sahip altı yığma minare sayısal olarak modellenmiş ve dört yer hareketi seviyesi için oluşturulan sentetik deprem hareketi altında analiz edilmiştir. Değiş̧en minare çapları için narinlik oranının belirlenmesi zor olduğundan, iki farklı şekilde araştırılmıştır.
\end{abstract}

Anahtar kelimeler: Yığma minareler, Deprem davranışı, Narinlik

\section{INTRODUCTION}

Minarets are one of the main components of mosques built next to, or jointed to the main wall of mosques. Classical Ottoman minarets are usually stone block or brick masonry, while the most of the contemporary ones are generally of reinforced concrete (RC). In Turkey majority of minarets have experienced notable partly or completely damages from past moderate to major destructive earthquakes. Mw=6.3 19 August 1999 Kocaeli and November 1999 Düzce earthquakes resulted with the collapse or heavily damages beyond repair of many minarets. Mw=7.2 23 October 2011 and Mw=5.6 9 November 2011, Van earthquakes heavily damaged or collapsed $63 \mathrm{RC}$ and masonry minarets.

The latest event of $\mathrm{Mw}=6.620$ July 2017 Muğla earthquake associated with a small tsunami caused some damages and collapse of one minaret in Bodrum. Seeing that a number of historical and modern minarets in Turkey, they will continue to suffer from devastating earthquakes. In the literature, some studies exist about dynamic behavior of minarets. Elwan (1996) studied the mechanical behavior of masonry minarets through seismic analysis of the minaret of the Al-Ghuri Mosque (46 m height), ancient Cairo, Egypt and proposed a method for the evaluation of the safety level of masonry minarets [1]. Seismic behavior of the Minaret of Dolmabahçe Mosque in Istanbul was investigated by creating its numerical model using the finite element method and estimated its mechanical properties through modal analysis [2]. Sezen et al. evaluated the fundamental 
IÖ. Saygllı

vulnerabilities and damages to 64 masonry and reinforced concrete minarets after the 1999 Kocaeli and Düzce Earthquakes were evaluated [3]. Acar et al. studied the response of a reinforced concrete minaret located on the four different subsoil classes defined in the Turkish Earthquake Code and concluded that the dynamic response of the minaret changes significantly depending on soil conditions [4]. The causes of extensive damage to reinforced concrete minarets were investigated by studying observed failure modes and their seismic performance during the 1999 Kocaeli and Düzce Earthquakes [5]. Representative reinforced and unreinforced minarets with 20, 25, and $30 \mathrm{~m}$ height were modeled and analyzed using two recorded ground motions to show the influence of minaret height to seismic behavior [6]. A stochastic seismic response analysis of masonry minarets subjected to random underground blast and earthquake-induced ground motion was studied by performing a parametric study to estimate the effects of the blast-induced ground motion on the stochastic response of the minaret. Study results showed that the stochastic dynamic response values increase with the increase of the blast charge weight, but decrease with the increase in the distance between the structure and blast center [7]. The dynamic response of masonry minarets before/after FRP composite strengthening was investigated through analyzing the numerical model under seismic loading [8]. Dynamic behavior of typical historical minarets in Istanbul made of natural block stone were investigated by using an ambient vibration approach and finite element method [9]. Valente and Milani showed the influence of some geometrical properties such as slenderness, inclination, and presence of openings and belfry on the seismic response of masonry towers through finite element models [10]. As inferred from the literature, minarets are tall and slender structures that are vulnerable to earthquakes. These structures should be analyzed differently from other form structures because of their complex behavior due to geometrical changes in the cross section of bodies, height and slenderness ratio. Damages and failures along the minaret were occasionally observed at the transition region and along the body. Representative images of the damages of the masonry minarets under seismic sequences are shown in Figure 1. As there are no structural code requirements or guidelines for the design of masonry minarets in Turkey, it is worthwhile to understand the effect of these special geometric parameters to the structural behavior. The aim of this study is to investigate the effect of slenderness ratio of minarets under synthetic ground motion and to quantify the impact of this parameter on structural demands, such as top displacement, stress and torsional moment.

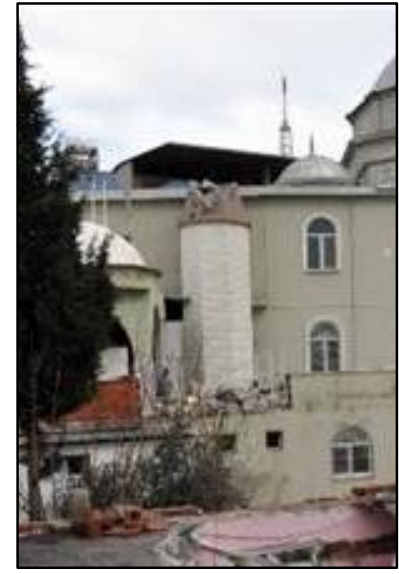

(a)

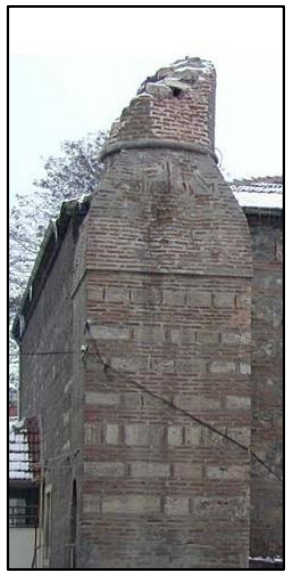

(b)

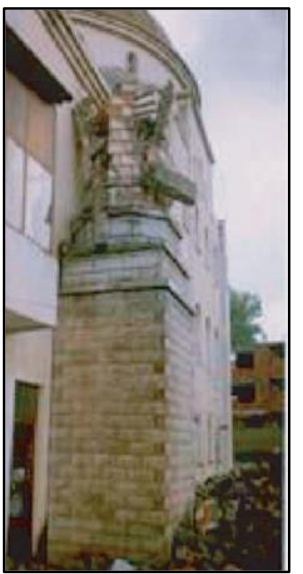

(c)

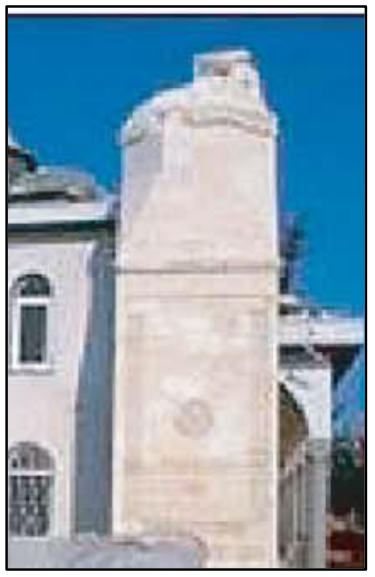

(d)

Figure 1. The collapsed minaret of Şafak Mosque, Izmir [11] (a), the minaret of SemsiAhmet Pasa mosque, Bolu (b), the minaret of Emir Bayırı Mosque, Yalova [12] (c) and collapse of one of the minaret in Adana [13] (d)

\section{FINITE ELEMENT MODELS OF MINARETS}

The three dimensional finite element analyses of minarets were carried out using the finite element software SAP2000 [14]. Shell elements were used to construct the spire, body, balcony and transition region of the minarets. Pulpits of the minarets were created using eight-node objects which have six quadrilateral faces with a joint at each corner. The main reason for using solid elements was to distribute the stiffness and mass accurately along the structure. The influence of various geometric parameters on the modal parameters and seismic behavior of the minarets like top displacement, modal oscillation, and base shear were examined. Representative six masonry minarets of different elevations and cross section diameters were numerically created. In order to investigate the effects of slenderness ratio, three minarets with the same diameter and varying heights were created. In the second place, keeping the heights constant, the external diameter of the body of the minarets and the height of the pulpit were increased. The first three minarets have elevations of $40 \mathrm{~m}, 50 \mathrm{~m}$ and $60 \mathrm{~m}$ with an external drum diameter of $3 \mathrm{~m}$ represented as D3-Minaret 1, D3-Minaret 2 and D3-Minaret 3 respectively. The second group of the three minarets has elevations of $40 \mathrm{~m}, 50$ 
$\mathrm{m}$ and $60 \mathrm{~m}$ with an external drum diameter of 4m named as D4-Minaret 1, D4-Minaret 2, D4-Minaret 3 respectively. The geometric parameters of minarets are given in Table 1. As it is difficult to determine the slenderness ratio for varying diameters, it was investigated in two ways. The ratio of the total height to the external diameter of the body, $\mathrm{Sr}_{1}\left(\mathrm{H} / \mathrm{D}_{\mathrm{b}}\right)$ and the ratio of the total body height to the external diameter of the body, $\mathrm{Sr}_{2}\left(\mathrm{H}_{\mathrm{b}} / \mathrm{D}_{\mathrm{b}}\right)$ were used as slenderness ratio for the six minarets. The slenderness ratios of the minarets are given in Table 2 . The boundary conditions were determined by restraining all degrees of freedom under the minarets. Another issue was the material properties. For the body of the numerical minaret models, weight density was considered as $20 \mathrm{kN} / \mathrm{m}^{3}$, Young's modulus (E) as $8.5 \times 10^{5} \mathrm{kN} / \mathrm{m}^{2}$. It was assumed that material properties of spire was wood with a weight density of $6 \mathrm{kN} / \mathrm{m}^{3}$. Stone spiral stairs were created with material properties with a weight density of $20 \mathrm{kN} / \mathrm{m}^{3}$, Young's modulus (E) of $10 \times 10^{6} \mathrm{kN} / \mathrm{m}^{2}$. The numerical minaret models including stairs are shown in Figure 2 . In the numerical models, a linear elastic material behavior was assumed.

Table 1. Geometrical properties of minarets (dimensions in $\mathrm{m}$ )

\begin{tabular}{lcccccc}
\hline \multicolumn{1}{c}{ Minaret } & $\begin{array}{c}\text { D3 } \\
\text { Minaret 1 }\end{array}$ & $\begin{array}{c}\text { D3 } \\
\text { Minaret 2 }\end{array}$ & $\begin{array}{c}\text { D3 } \\
\text { Minaret 3 }\end{array}$ & $\begin{array}{c}\text { D4 } \\
\text { Minaret 1 }\end{array}$ & $\begin{array}{c}\text { D4 } \\
\text { Minaret 2 }\end{array}$ & $\begin{array}{c}\text { D4 } \\
\text { Minaret 3 }\end{array}$ \\
\hline $\begin{array}{l}\text { Pulpit } \\
\begin{array}{l}\text { Height } \\
\text { Transition }\end{array}\end{array}$ & 10 & 10 & 10 & 10 & 10 & 10 \\
$\begin{array}{l}\text { Height } \\
\text { Body }\end{array}$ & 9 & 9 & 9 & 5 & 5 & 5 \\
$\begin{array}{l}\text { Height } \\
\begin{array}{l}\text { External } \\
\text { Diameter }\end{array}\end{array}$ & 21 & 31 & 41 & 25 & 35 & 45 \\
$\begin{array}{l}\text { Internal } \\
\text { Diameter }\end{array}$ & 2.4 & 3 & 3 & 4 & 4 & 4 \\
\hline
\end{tabular}

Table 2. Slenderness ratios of minarets

\begin{tabular}{ccc}
\hline Minaret & $\begin{array}{c}\text { Slenderness Ratio 1 } \\
\left(\mathbf{S r}_{1}\right) \\
\left(\mathbf{H}_{\text {total }} / \mathbf{D}_{\text {body }}\right)\end{array}$ & $\begin{array}{c}\text { Slenderness Ratio 2 } \\
\left(\mathbf{S r}_{2}\right) \\
\left(\mathbf{H}_{\text {body }} / \mathbf{D}_{\text {body }}\right)\end{array}$ \\
\hline D3-Minaret 1 & 10.0 & 7.0 \\
D3-Minaret 2 & 13.3 & 10.3 \\
D3-Minaret 3 & 16.7 & 13.7 \\
D4-Minaret 1 & 7.5 & 6.3 \\
D4-Minaret 2 & 10.0 & 8.8 \\
D4-Minaret 3 & 12.5 & 11.3 \\
\hline
\end{tabular}


I Ö. Saygll

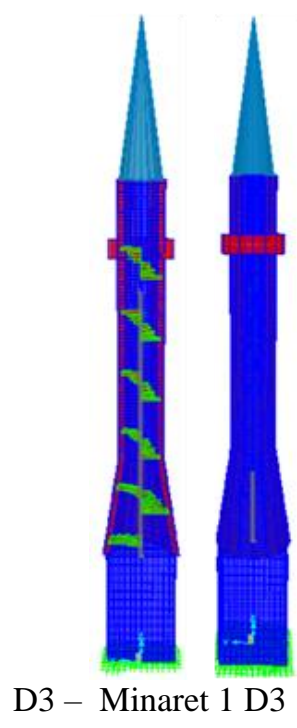

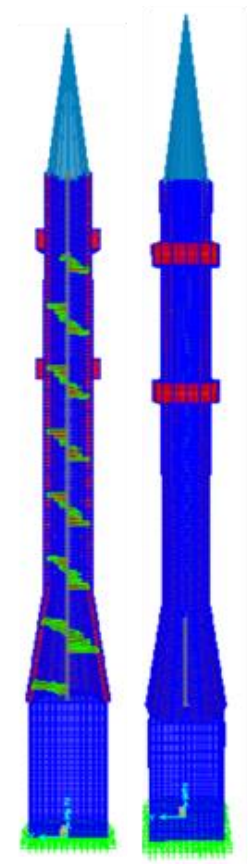

Minaret 2 D3
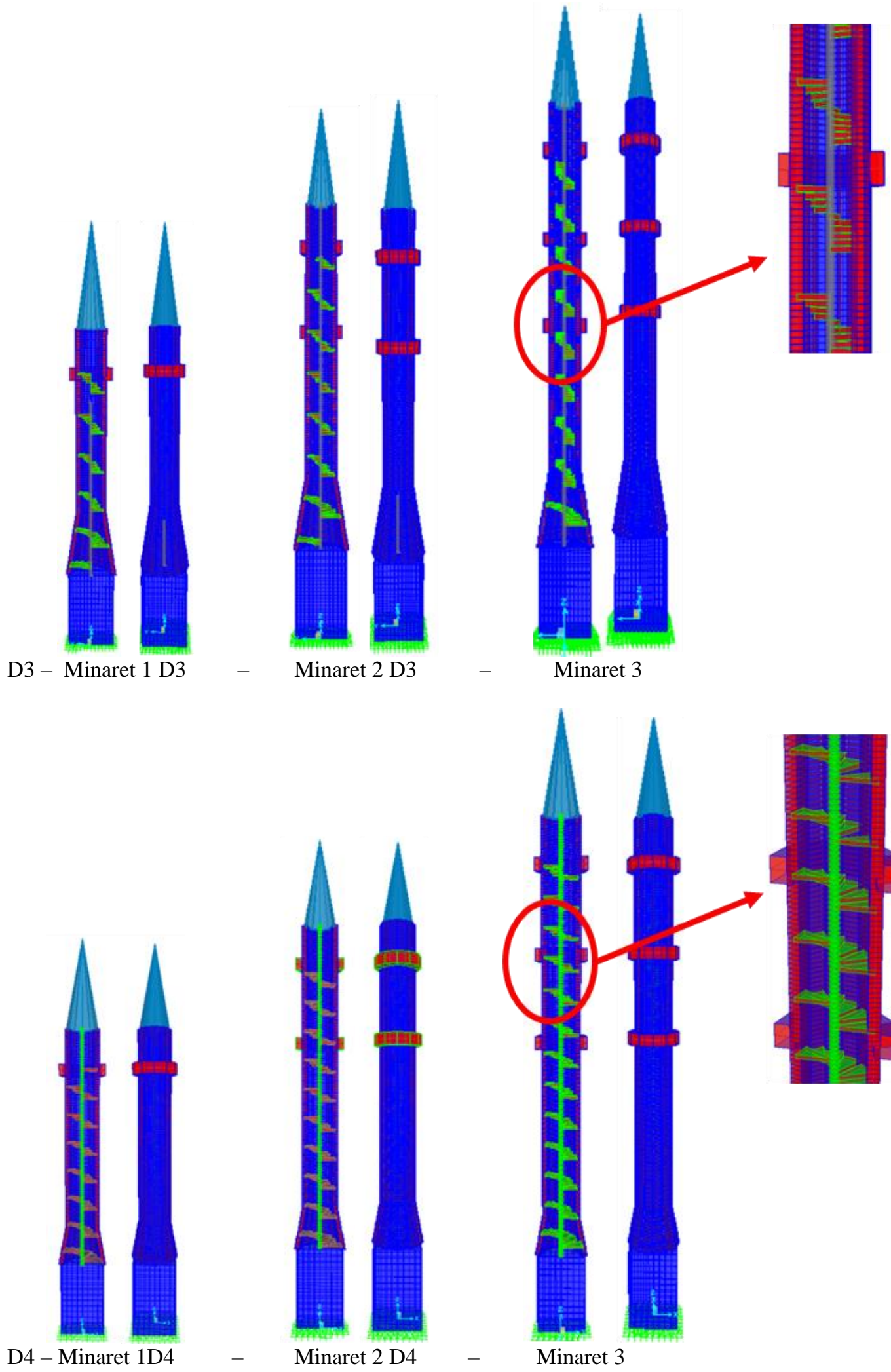

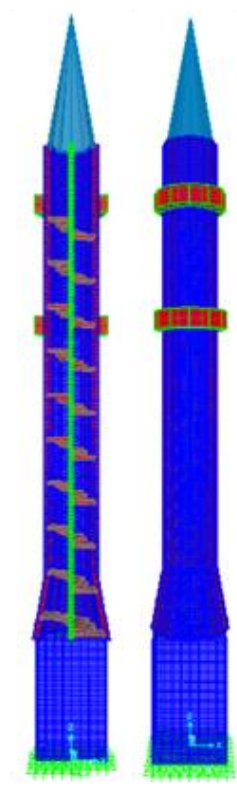

Minaret 2 D4

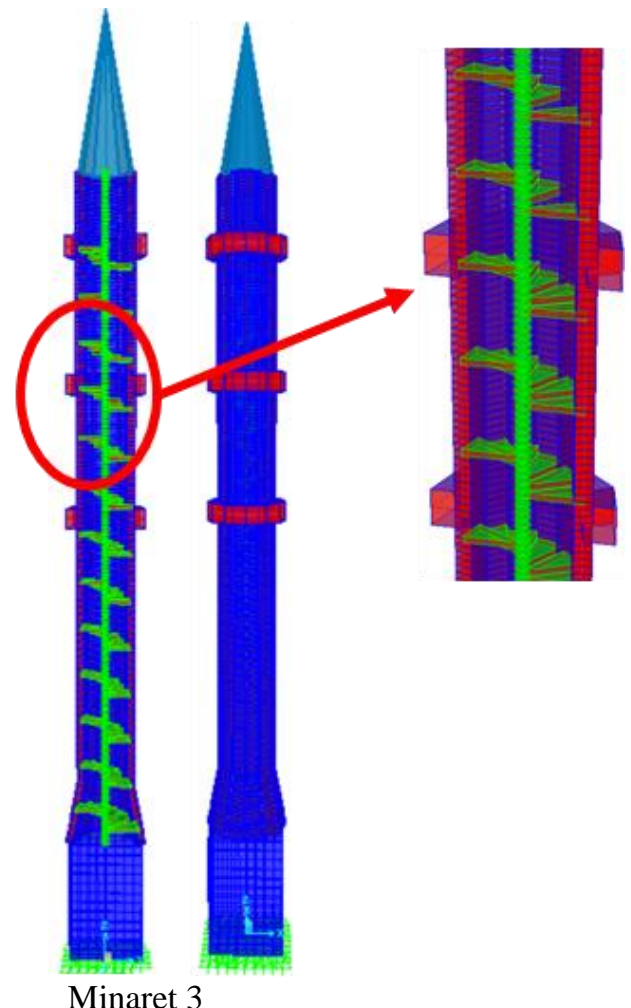

Figure 2. Numerical minaret models 


\section{MODAL ANALYSES RESULTS}

Minarets numerically modeled as vertical cantilever fixed at the base with varying cross sections were statically analyzed in order to obtain the natural frequencies and mode shapes. For the static analysis of the minarets, self-weight and gravity were considered. Representative first six mode shapes of the two minarets obtained from the analytical modal analysis are given in Figure 3. It is evident from the figures that mode shapes are almost similar. As the numerical models have an orthogonal symmetry, the natural periods of the first and second modes are very close to each other. Structural characteristics of natural periods, natural frequencies and dynamic mass participation factors were determined for the first six modes of the minarets. The first periods are $0.72,1.36,2.07$ seconds for the minaret of 1, 2 and 3 with an external diameter of $3 \mathrm{~m}$, respectively. For the second case, periods are $0.76,1.24,2.02$ seconds for the minaret of 1,2 and 3 with an external diameter of $4 \mathrm{~m}$, respectively. Variation of natural periods with respect to slenderness ratio 1, $\mathrm{Sr}_{1}$ and slenderness ratio $2, \mathrm{Sr}_{2}$ are depicted in Figure 4. It was observed from the data given in Figure 4 that the fundamental natural period increases with the increase in $\mathrm{Sr}_{2}$, which is not obvious for the $\mathrm{Sr}_{1}$. Although the D3-minaret1 (40 m with ext. diameter of $3 \mathrm{~m}$ ) has the higher slenderness ratio 1 than the D4minaret1 ( $40 \mathrm{~m}$ with ext. diameter of $4 \mathrm{~m}$ ), the period is lower than that of the minaret with the lowest slenderness ratio 1 . The obtained results showed that deformed shapes are similar and the torsional modes for six minaret take place in lower periods. In addition, the relation between the natural period and mass participation was evaluated. The results showed that the mass participation of a free vibration modes of all minarets were lower than $80 \%$. The presence of higher modes as between sixth and twelfth, mass participation were in the range of $15 \%$ to $20 \%$ of the total mass which is inconsiderable for slender structures.

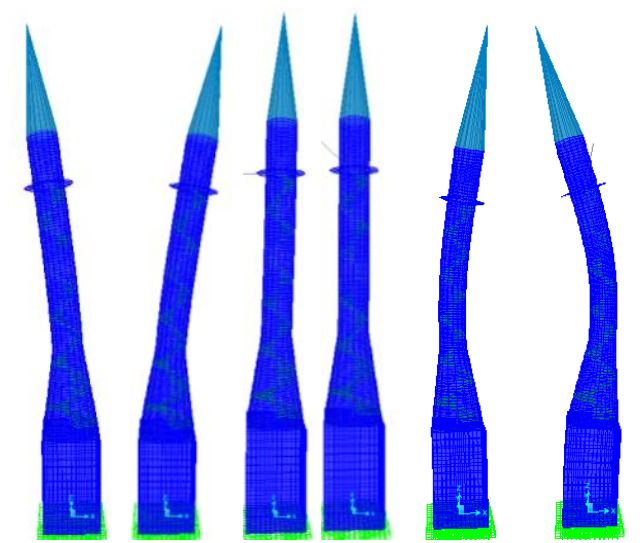

Mode 1-Mode 2-Mode 3-Mode 4-Mode 5-Mode 6

(a)

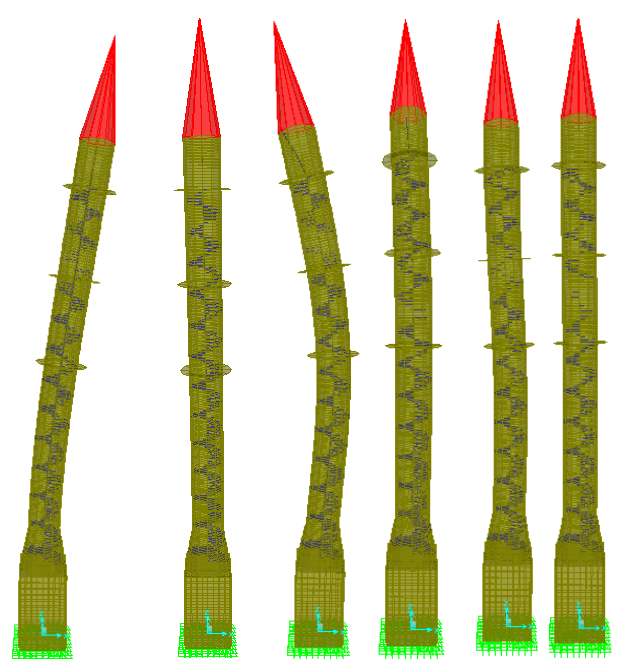

Mode 1-Mode 2-Mode 3-Mode 4-Mode 5-Mode 6

(b)

Figure 3. First six mode shapes of the $40 \mathrm{~m}$ height of the minarets with external drum diameter of $3 \mathrm{~m}$ (a) and $60 \mathrm{~m} \mathrm{height} \mathrm{of}$ the minarets with external drum diameter of $4 \mathrm{~m}(\mathrm{~b})$ 
IÖ. Saygllı
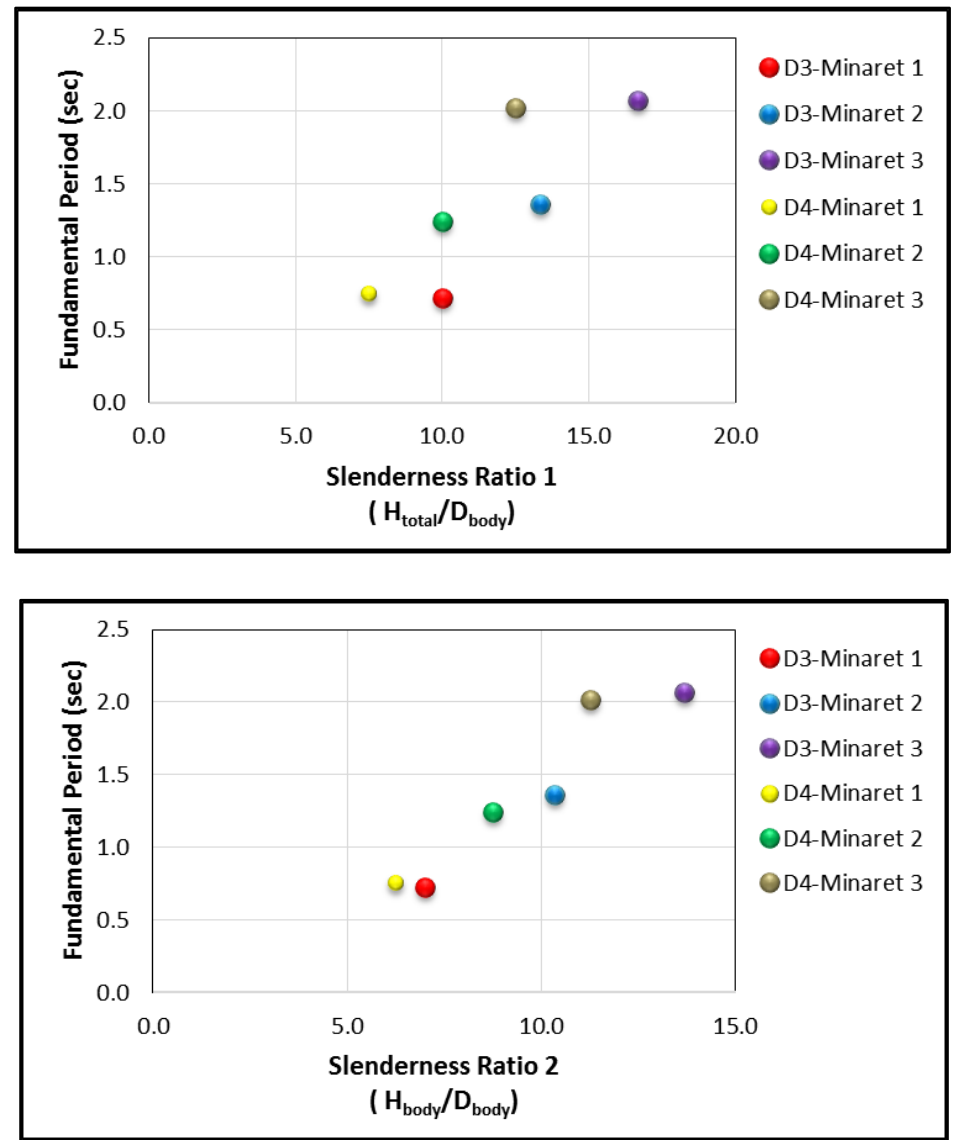

Figure 4. Variation of natural periods with respect to slenderness ratio $1, \mathrm{Sr}_{1}$ and slenderness ratio $2, \mathrm{Sr}_{2}$

\section{TIME HISTORY ANALYSIS}

Synthetic ground motions were created to perform the time history analyses. Four types of ground shaking levels given in the Turkish Seismic Code 2018 were taken into consideration in creating the synthetic time series. Synthetic excitations were created for soil class C. For each level one artificial ground motion compatible with design response spectrum was simulated using Seismosoft software [15]. The first earthquake ground motion level had a $2 \%$ probability to be exceeded in 50 years. The return period of this ground shaking was 2475 years. Peak ground acceleration (PGA) of the first synthetic motions was $0.677 \mathrm{~g}$ and peak ground velocity (PGV) was $71.31 \mathrm{~cm} / \mathrm{sec}$. The second earthquake ground motion level had a $10 \%$ probability to be exceeded in 50 years. Return period of this ground shaking was 475 years. PGA of the synthetic motion was $0.399 \mathrm{~g}$ and PGV was $55.92 \mathrm{~cm} / \mathrm{sec}$. The third earthquake ground motion level had a $50 \%$ probability to be exceeded in 50 years with a return period of 72 years. PGA of the synthetic motion was $0.167 \mathrm{~g}$ and PGV was $17.19 \mathrm{~cm} / \mathrm{sec}$. The fourth ground motion level had a $50 \%$ probability to be exceeded in 68 years. Return period of this ground shaking was approximately 43 years. PGA of the synthetic motion was $0.109 \mathrm{~g}$ and PGV was $12.38 \mathrm{~cm} / \mathrm{sec}$. Acceleration time histories of the synthetic ground motion for each level are shown in Figure 5. 

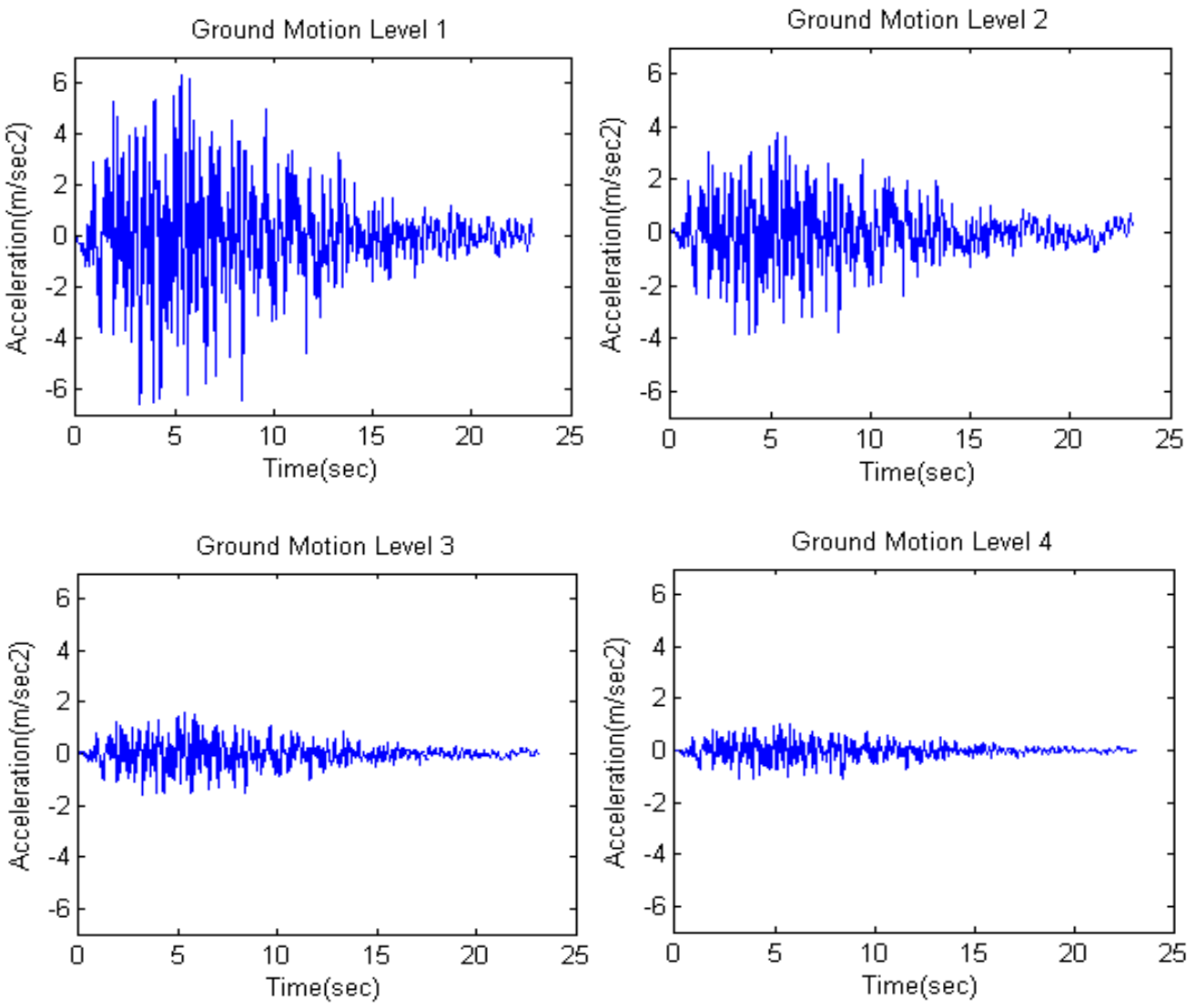

Figure 5. Acceleration time histories of the synthetic ground motion for four ground motion level

The modal analyses results are not sufficient to explain the influence of slenderness ratio on the seismic behavior of the masonry minarets; hence, time history analyses were carried out. The responses of minarets in terms of maximum lateral top deflection, shear stress and torsional moment were investigated. For the time history analysis, the Newmark direct integration approach which yields to the constant average acceleration method was used. The methodology is based on the integration of structural properties and behaviors at a series of time steps which are small relative to loading duration. The technique is based on performing an Integration at every time step of the input record [14]. The variation of top displacement with respect to slenderness ratio $1, \mathrm{~S}_{\mathrm{r} 1}$ and slenderness ratio $2, \mathrm{~S}_{\mathrm{r} 2}$ for four ground motion level are depicted in Figure 6 . It is seen that for ground motion level 1, the maximum displacement observed at the top of the minarets increased with the increase of slenderness ratio 2 which is not obvious for the lower ground motion levels. Considering ground motion level 4, although the D3-minaret 2 has higher slender ratio than the D3-minaret 1, experienced lower top displacement. For ground motion level 2 and 3, we observed a slight increase of top displacement with the increase of the $S_{\mathrm{r} 1}$ and $S_{\mathrm{r} 2}$. However, it clear from ground motion level 1, $\mathrm{S}_{\mathrm{r} 2}$ cause an increase in top lateral displacement. It can be concluded that an increase in the body height, without considering the transition height, resulted in larger lateral deformation. The $60 \mathrm{~m}$ height of the minaret with a drum diameter of $3 \mathrm{~m}$ experienced maximum deflection, while the minaret with the lowest slenderness ratio (D4-minaret 1) experienced minimum lateral displacement. In addition, maximum torsional moments in minarets obtained from the time history analyses were evaluated. The variation of torsional moment at the base of the minarets with respect to slenderness ratio $1, \mathrm{~S}_{\mathrm{r} 1}$ and slenderness ratio $2, \mathrm{~S}_{\mathrm{r} 2}$ for four ground motion level are shown in Figure 7. It is seen that maximum torsional moments were obtained from the minaret with lowest slenderness ratio (D4-minaret 1) for each ground motion level. For ground motion level 1, there is a slight difference between the observed base torsional moments from three minarets with $3 \mathrm{~m}$ drum diameter. Nevertheless, for the same ground motion level, minarets with a $4 \mathrm{~m}$ drum diameter experienced torsional moments in range of $75-225 \mathrm{kNm}$. The results show that, there is no clear correlation between the slenderness ratio and base torsional moment which can be improved by increasing the number of minarets and considering the staircase and balconies. 
IÖ. Saygllı
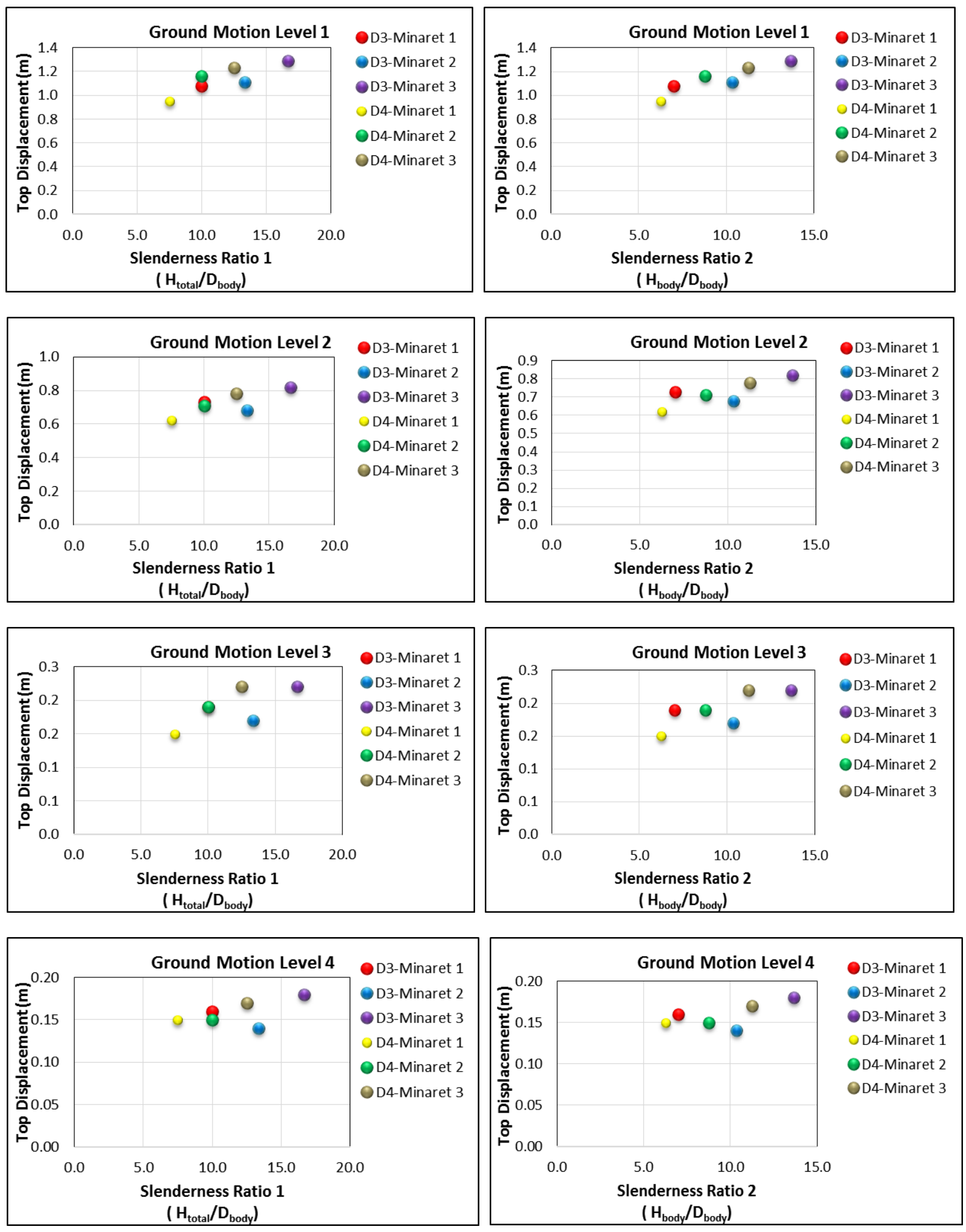

Figure 6. Variation of top displacement with respect to slenderness ratio 1, Sr1 and slenderness ratio 2, Sr2 for four ground motion level 
INVESTIGATION OF THE EFFECT OF SLENDERNESS RATIO ON THE STRUCTURAL RESPONSE OF MASONRY MINARETS
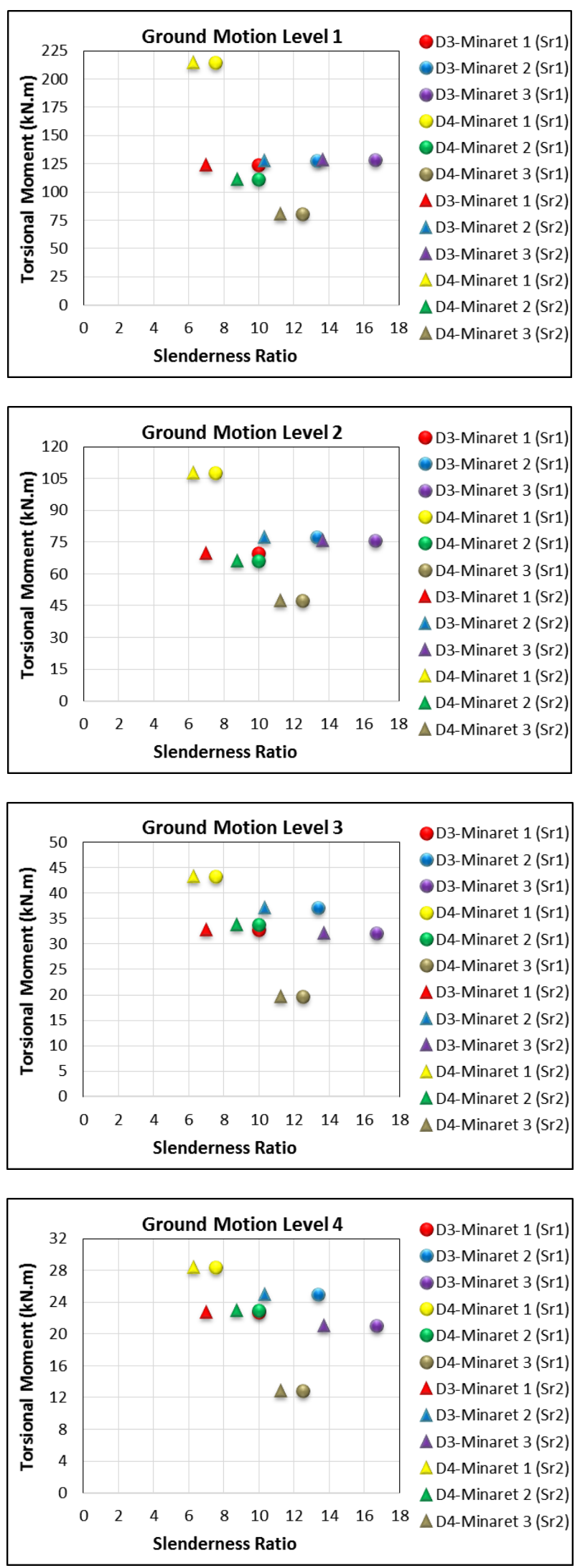

Figure 7. The variation of torsional moment at the base of the minarets with respect to slenderness ratio 1 , $\mathrm{S}_{\mathrm{r} 1}$ and slenderness ratio $2, \mathrm{~S}_{\mathrm{r} 2}$ for four ground motion level 
IÖ. Saygllı

In addition, variations of shear stress along the minarets were observed. Representative stress distribution along the first group of minarets with drum diameters of $3 \mathrm{~m}$ and second group of minarets with drum diameters of $4 \mathrm{~m}$ under the synthetic excitation for ground motion level 1 are shown in Figure 8. It is observed from the results that the maximum shear stresses are concentrated at the transition segment and the balcony level. As stated, the damages and failures along the minaret were occasionally observed at the transition region, therefore, more research is needed to assess the influence of this part of the minarets.

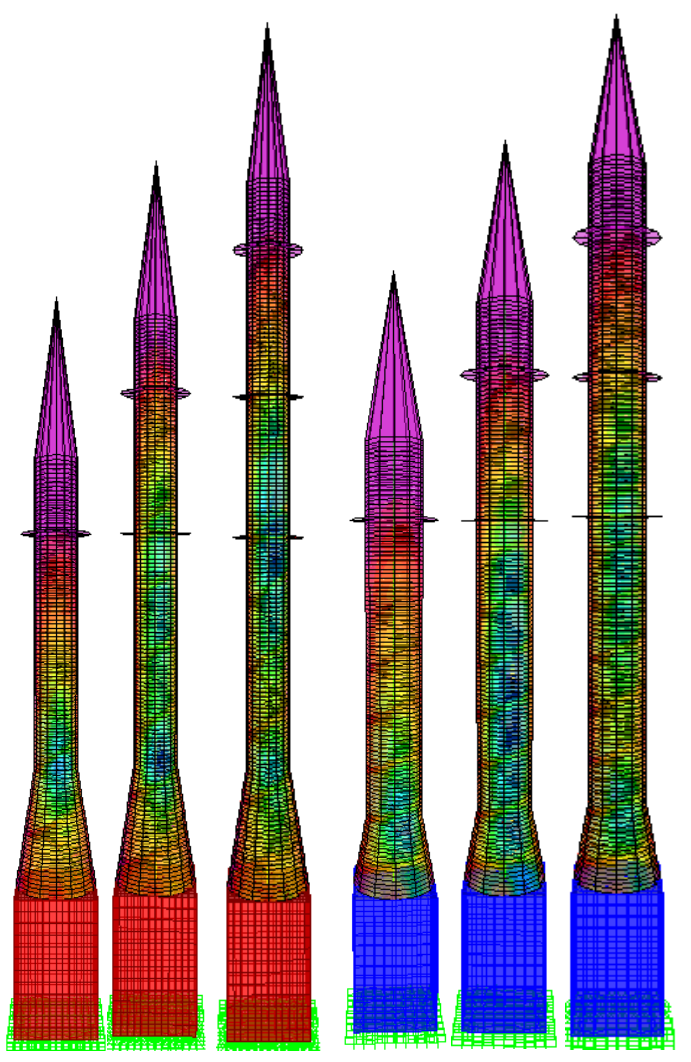

Figure 8. Variation of shear stresses along the first group of minarets with drum diameter of $3 \mathrm{~m}$ (a) and second group of minarets with drum diameter of $4 \mathrm{~m}$ (b) for ground motion level 1

\section{CLOSING REMARKS}

This study focuses on studying the effect of slenderness ratio of minarets to structural behavior. Six minarets in different diameter and heights were selected to carry out the target study. Numerical minaret models were created by finite element software SAP2000. Two different slenderness ratios were considered. The first results on the minarets were obtained from standard modal analyses. In the next step, time history analyses were performed under four synthetic loadings created based on the Turkish Seismic Code 2018. As the fundamental period had a great effect on the investigation of the seismic vulnerability of slender structures, the influence of the slenderness ratio on the natural periods was evaluated. Through the analysis of the study, results show that torsional modes take place in lower periods for all minarets. It was also found that the natural frequency of the minarets increased with an increase in Slenderness Ratio 1, which is defined as the ratio of the total height to the external diameter of the body. It was observed from the modal analysis that the contribution of the first two modes to the dynamic responses are in the range of \%33-\%40, in X direction. The higher modes affect the dynamic behavior of slender masonry minarets. The data obtained from the results of the time history analyses show that the top displacement of the minarets increased with an increase of slenderness ratio. It can be concluded that the dynamic response of the minarets is highly affected by the slenderness ratio. Increase in the body height, without considering the transition height, resulted in larger lateral deformation. The $60 \mathrm{~m}$ height of the minaret with a drum diameter of $3 \mathrm{~m}$ experienced maximum deflection, while the minaret with the lowest slenderness ratio (D4-minaret 1) experienced minimum lateral displacement.

In addition, maximum torsional moments in minarets obtained from time history analyses were evaluated. The observed data from the variation of torsional moment at the base of the minarets with respect to slenderness ratio $1, \mathrm{~S}_{\mathrm{r} 1}$ and slenderness ratio 2 , 
$\mathrm{S}_{\mathrm{r} 2}$ show that there is no clear correlation between the slenderness ratio and base torsional moment which can be improved by increasing the number of minarets and considering the staircase and balconies. More research is needed to assess the influence of balcony and stairs on the seismic response. Throughout history, having witnessed many devastating earthquakes which occur in Turkey because of the active tectonic regime controlling most of the regions in the country, show that they are slender structures vulnerable to earthquake. It is definitely necessary to develop a seismic evaluation code and guidelines for the maintenance and preservation of historical masonry minarets.

\section{REFERENCES}

[1] S. H. Elwan, Seismic Response of Historical Masonry Minarets. Ph.D. Dissertation, Faculty of Engineering, Ain Shams University, Cairo. 1996.

[2] M. Oğuzmert, Yığma Minarelerin Dinamik Davranışı. M.Sc. Thesis, Istanbul Technical University, Istanbul. 2002.

[3] H. Sezen, G. Y. Firat, M. A. Sözen, "Investigation of the performance of monumental structures during the 1999 Kocaeli and Düzce earthquakes," Proceedings of the Fifth National Conference on Earthquake Engineering, AE-020, Istanbul, Turkey, 2003.

[4] R. Acar, R. Livaoğlu, A. Doğangün, H. Sezen, "The effect of subsoil on the seismic response of reinforced concrete cylindrical minarets," Proceedings of Fifth International Conference on Seismology and Earthquake Engineering, International Institute of Earthquake Engineering and Seismology (IIEES), Tehran, Iran, 2007.

[5] H. Sezen, R. Acar, A. Doğangün, R. Livaoglu, "Dynamic analysis and seismic performance of reinforced concrete minarets," Engineering Structures, vol. 30, pp. 2253-2264, 2008.

[6] A. Doğangün, R. Acar, H. Sezen, R. Livaoğlu, "Investigation of dynamic response of masonry minaret structures," Bulletin of Earthquake Engineering, vol. 6, no. 3, pp. 505-517, 2008.

[7] K. Haciefendi, B. Fahri, "Stochastic dynamic response of masonry minarets subjected to random blast and earthquakeinduced ground motions," The Structural Design of Tall and Special Buildings, vol. 20, pp. 669-678, 2011.

[8] A. C. Altunışık, "Dynamic response of masonry minarets strengthened with fiber reinforced polymer (FRP) composites", Natural Hazards and Earth System Sciences, vol. 11, pp. 2011-2019, 2011.

[9] C.S. Oliveira, E. Çakti, D. Stengel, M. Branco, "Minaret behavior under earthquake loading: The case of historical Istanbul," Earthquake Engineering and Structural Dynamics vol. 41, pp. 19-39, 2012.

[10] M. Valente, G. Milani, "Effects of geometrical features on the seismic response of historical masonry towers," Journal of Earthquake Engineering, vol. 22, pp. 2-34, 2018.

[11] Cumhuriyet, http://www.cumhuriyet.com.tr. 2015.

[12] Y. Firat, State of Minarets Regarding August 17,1999, Izmit Earthquake. http://www.anatolianquake.org/, 1999.

[13] T. Wenk, C. Lacave, K. Peter, "The Adana-Ceyhan Earthquake of June 27, 1998", Report on the Reconnaissance Mission, Swiss Society of Earthquake Engineering and Structural Dynamics (SGEB). Zurich, Switzerland, 1998.

[14] SAP2000, Integrated structural analysis and design software, Computer and Structures Inc., Berkeley, California, 2014.

[15] SeismoSoft, SeismoArtif, version 1.0.0 2012: SeismoArtif’s help system 2002-2012. Seismosoft Ltd., 2012. 